\title{
Rate of dark respiration of oats at various levels of copper supply
}

\author{
EWA ZINKIEWICZ, MARIA RUSZKOWSKA, HALINA SAMIEC
}

Laboratory of Plant Nutrition, Institute of Soil Science and Cultivation of Plants, Osada Pałacowa, 24-100 Puławy, Poland

〈Received: March 4, 1983〉

\begin{abstract}
The aim of the present study was to determine the intensity of dark respiration of oat plants cv. 'Udycz Żólty' during their vegetation period. Plants were grown with addition of increasing doses of copper, applied at different stages of development. Up to heading of the control plants, copper-deficient plants showed low intensity of dark respiration as compared with the copper-sufficient plants. After heading, a strong increase in the rate of respiration in the former was noted. The high intensity of dark respiration in copper-deficient plants after heading was probably the result of ineffective utilization of assimilates in the absence of the panicle - the main acceptor of the photosynthesis products.
\end{abstract}

\section{INTRODUCTION}

There are numerous papers, available in the literature, concerning the influence of copper on the yield of cereals. Some of them are connected with the influence of copper on the growth and development of plants 〈B r o w n et al., 1958; G r a h a m, 1975; 1980; N a m b i a r, 1976, part I; Os t r ovsk y a, 1961; R a h i m i and B us s le r, 1973; Szuk a l$\mathrm{s} \mathrm{k} i$ et al., 1980 $>$. In others, genotypic differences in the degree of sensitivity to copper deficiency have been reported $\langle\mathrm{N}$ a m b i a r, 1976, parts I and II $\rangle$. The influence of copper deficiency on the structure of tissues of higher plants $\langle\mathrm{R}$ a h i m i and B u s s le r, 1973〉 and on anatomo-morphological changes in the inflorescences $\langle\mathrm{W}$ e $\mathrm{r}$ y s z k o et al., 1983〉 has been also described. There has been studied the effect of copper on photosynthesis $\langle\mathrm{B}$ a s z y ń s k i et al., 1978 $\rangle$ and on carbohydrate metabolism in plants $\langle\mathrm{B} \mathrm{r}$ o w n et al., 1958 $\rangle$. It has been attempted to elucidate why, under conditions of copper deficiency, plants do not set seeds $\langle\mathrm{G} \mathrm{r}$ a h a m, 1975 $\rangle$. It has been found, that the processes occurring in plants in the generative phase requir a higher copper supply than those in the vegetative phase $\langle\mathrm{B} \mathrm{r}$ o $\mathrm{w} \mathrm{n}$ et al., 1958; $\mathrm{G} \mathrm{r}$ a h a m, 1975; N a m b i a r, 1976, part I; O s t r o v s k a y a, 1961 $>$. More recently 
attention has been devoted to the problem how the date of copper application, in the form of soil fertilization or spraying the plants, influences the growth and development of plants as well as the yield of grain $\langle\mathrm{G} \mathrm{r}$ a $\mathrm{h}$ a $\mathrm{m}$, 1976; $\mathrm{N}$ a $\mathrm{m} \mathrm{b}$ i a r, 1976, part I $\rangle$. However, there are only few reports on the influence of copper on plant respiration. The earliest study $<$ Le Van - quoted by O s t r ov s k a y a, 1961> concerns the action of salts of various metals 〈including $\mathrm{Cu}$ > on respiration of white lupin plants.

Recently the influence of copper deficiency on crop plants with particular reference to cereals has been examined in details in the Laboratory of Plant Nutrition of the Institute of Soil Science and Cultivation of Plants in Pulawy 〈 $\mathrm{y} \mathrm{s} \mathrm{z} \mathrm{c} \mathrm{z} \mathrm{et} \mathrm{al.,} \mathrm{1976;} \mathrm{R} \mathrm{u} \mathrm{s} \mathrm{z} \mathrm{k} \mathrm{o} \mathrm{w} \mathrm{s} \mathrm{k} \mathrm{a} \mathrm{and} Ł$ y s z c z, 1971; 1975; R u s z k ow s k a et al., 1976; W o j c i e s k a, 1982; parts I and II; 1983, parts III, IV; Z i n k i e w i c z, 1978; Z i n k i e w i c z et al., 1980; Z i n$\mathrm{k}$ i e w i c z and S l u s a r c z y k, 1981). On the basis of these investigations the present study was undertaken to elucidate the influence of copper on the rate of dark respiration of oats, at various developmental stages, at various levels of copper supply and at different dates of $\mathrm{Cu}$ application.

\section{MATERIAL AND METHODS}

Pot experiments were performed in the period 1976-1980 with oat plants $\langle$ Avena sativa L. >, cv. 'Udycz Żółty'. The plants were cultivated in pots filled with low peat $\langle 0.8 \mathrm{~kg} \mathrm{DWt}\rangle$ deficient in copper, $\mathrm{pH}\langle\mathrm{KCL}\rangle 6.7$. From the beginning of plant vegetation the copper supply was as follows:

$$
\begin{aligned}
& \mathrm{Cu}-0-\text { control }\langle\text { severe deficiency } \text {, } \\
& \mathrm{Cu}-5-5 \mathrm{mg} \mathrm{Cu} / \text { pot }\langle\text { moderate deficiency }\rangle \text {. }\langle\text { This treatment was } \\
& \text { introduced only in } 1977 \text { and 1979 }\rangle \text {, } \\
& \mathrm{Cu}-125-125 \mathrm{mg} \mathrm{Cu} / \text { pot 〈optimal supply } \text {. }
\end{aligned}
$$

Copper was given in the form of $\mathrm{CuSO}_{4} \cdot 5 \mathrm{H}_{2} \mathrm{O}$. The remaining mineral nutrients were supplied to the plants in optimal quantities before sowing and during their vegetation. To elucidate the influence of copper applied at various stages of development on the dark respiration rate, in 1979 and 1980 additional treatments were introduced. Namely, the optimal copper dose $\langle\mathrm{Cu}$ $-125 \mathrm{mg} / \mathrm{pot}\rangle$ was given at the following stages: tillering, shooting, heading and flowering of oats. Up to mentioned stages the plants grew with a complete absence of copper. Plants receiving an optimal $\mathrm{Cu}$ supply immediately after emergence served as a control.

Dark respiration was measured by means of an Infralyt III gas analyser in a closed system. The results <means of two determinations> were expressed in $\mathrm{mg} \cdot \mathrm{h}^{-1} \cdot \mathrm{g}^{-1} \mathrm{DWt}$. The data was statistically elaborated by the variance with the $F$ test and Tukey's confidence semi-intervals analysis.

The measurements of dark respiration were preformed on the main shoot

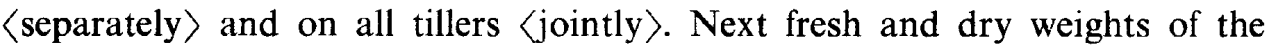


analysed shoots were determined. The following developmental stages $<$ determi ned on the basis of the main shoot in the treatment $\mathrm{Cu}-125\rangle$ were taken into account: shooting, before heading, heading, filling of grain and grain ripeness milk, milk-dough, dough, dough-full and full. At the time of respiration measurement additional plants were harvested for determination of the dry weight yield.

\section{RESULTS}

It has been noted that copper significantly influenced the growth and development of oat plants. The results concerning the yield and its structure have been presented in detail in separate publications $\langle\mathrm{W}$ o j c i e s $\mathrm{k}$ a, 1982, parts I and II $>$.

The degree of copper supply had a significant influence on the dark respiration rate of oat plants. This effect depended on the developmental stage of plants $\langle$ Fig. 1$\rangle$. Up to heading and even as late as the middle stage of grain filling, there was observed higher rate of dark respiration in main shoots treated with $\mathrm{Cu}$ -125 in comparison with the $\mathrm{Cu}-0$ one. From the heading or grain filling stages to the end of measurements, that is to the dough or full ripeness, the above mentioned dependence was reversed - the respiration rate of the main shoot in the $\mathrm{Cu}-0$ treatment was higher than in the plants well supplied with $\mathrm{Cu}$. The difference became bigger with the age of the plants. In the tillers, however, the respiration intensity of $\mathrm{Cu}-0$ plants was always higher than that in shoots of the $\mathrm{Cu}-125$ treatment, notwithstanding the developmental stage of the plants $\langle$ Fig. 1 $>$.

In the experiments in 1977 and 1979 the treatment $\mathrm{Cu}-5$ was introduced. It was stated that the respiration rate of plants in this treatment had an intermediate value in comparison with plants showing copper deficiency symptoms and those optimally supplied with this nutrient 〈Fig. 1〉. There were, however, certain differences: in 1977 the respiration rate of the $\mathrm{Cu}-5$ plants was close to the low value obtained for the $\mathrm{Cu}-125$ plants, whereas in 1979 it was closer to the higher intensity of respiration of the $\mathrm{Cu}$-deficient plants $\langle$ Table 1$\rangle$.

The respiration rate of tillers was always higher than that of the main shoots, copper supply independent $\langle$ Fig. 1$\rangle$.

There were some statistical significant differences in dark respiration intensity, notwithstanding the developmental stages: between tillers of copper-deficient plants $\langle\mathrm{Cu}-0\rangle$ and those with abundant copper supply $\langle\mathrm{Cu}-125\rangle$, as well as between tillers of $\mathrm{Cu}-0$ and of moderate shortage $\langle\mathrm{Cu}-5\rangle$. Significant differences concernig individual stages were as followed: in the case of main shoots - only before heading between $\mathrm{Cu}-0$ or $\mathrm{Cu}-5$ plants, and $\mathrm{Cu}-125$ plants; in tillers - in the milk-dough, dough and full ripeness stages between $\mathrm{Cu}$ -0 and $\mathrm{Cu}-125$ plants. 


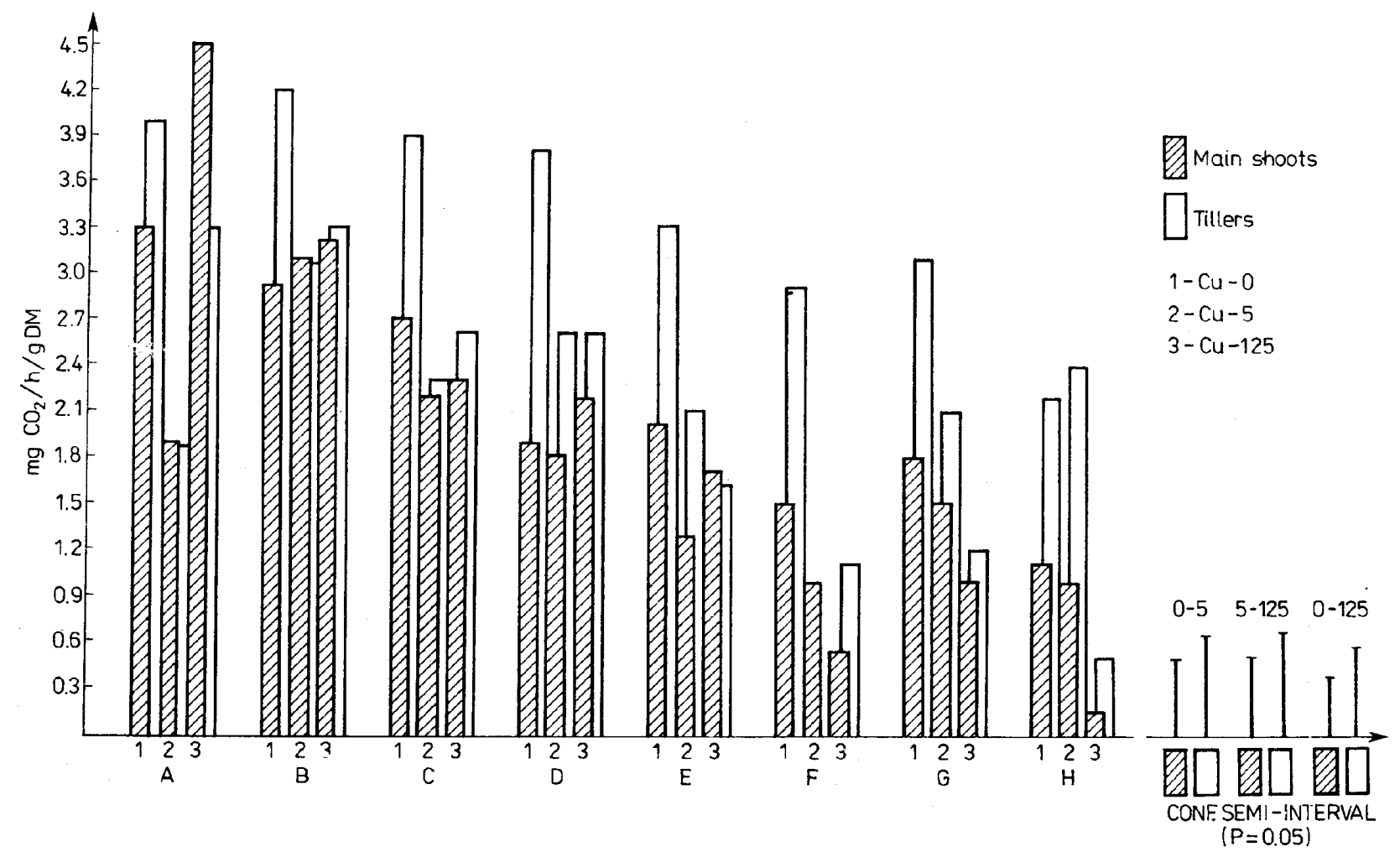

Fig. 1. Effect of copper on dark respiration rate of oat plants at different stages of development. $1-\mathrm{Cu}-0,2-5 \mathrm{mg} \mathrm{Cu} / \mathrm{pot}, 3-125 \mathrm{mg} \mathrm{Cu} /$ pot given at sowing. Measurements in phase: A - before heading, B - heading, C - flowering, D - grain filling, E - milk stage, F - milk-dough stage, G - dough stage, $\mathrm{H}$ - full ripeness. 〈Means of 5 years >. Confidence semi-intervals independent of date of measurement 


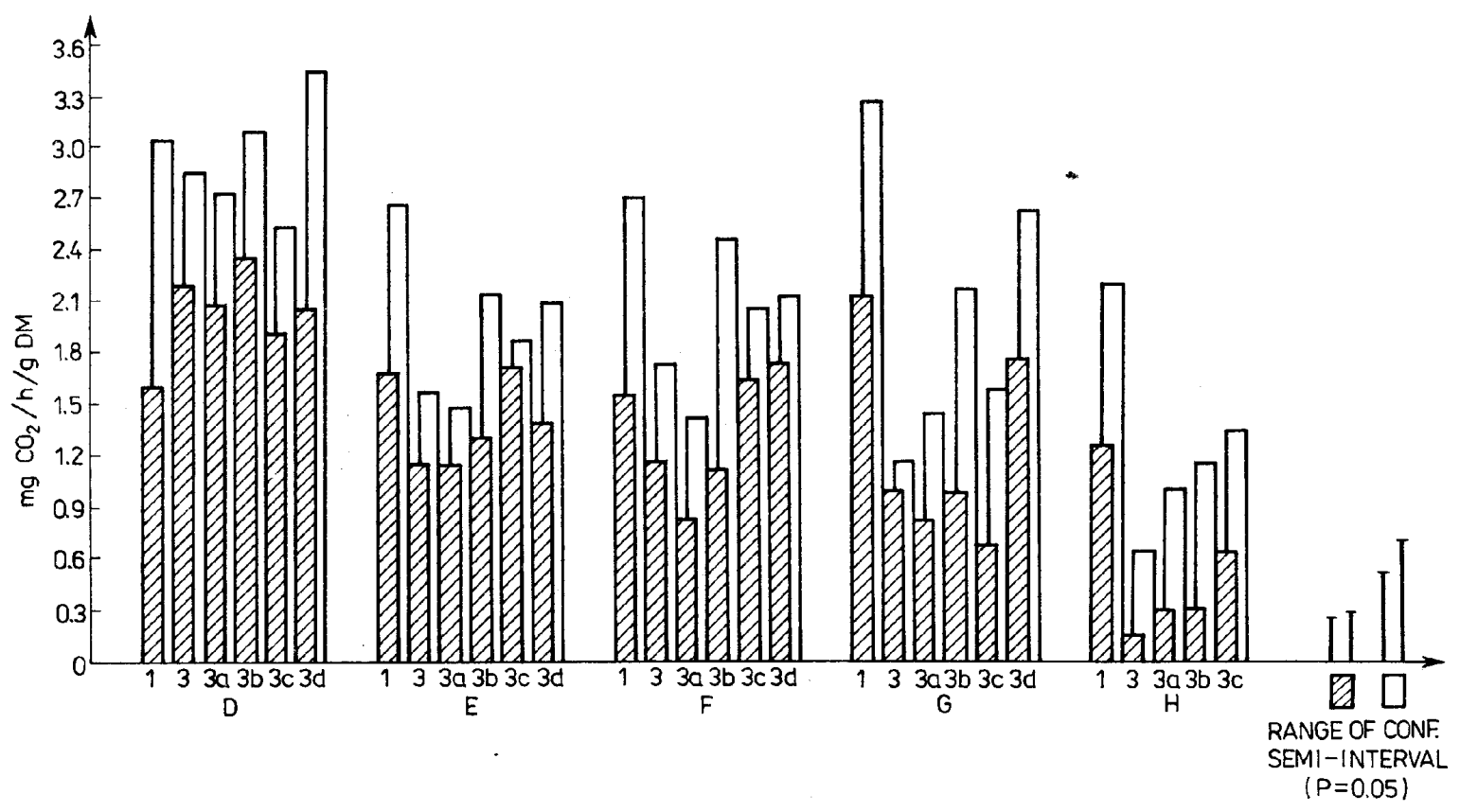

Fig. 2. Dark respiration with optimal copper dose supplied at different stages of plant development. $1-\mathrm{Cu}-0,3-\mathrm{Cu}-125 \mathrm{mg} \mathrm{Cu} /$ pot given at sowing, $3 \mathrm{a}$ - tillering, $3 \mathrm{~b}-$ shooting, $3 \mathrm{c}-$ heading, $3 \mathrm{~d}$ - flowering. 〈Means of 2 years〉. Other explanations as in Fig. 1 
Table 1

Effect of copper on dark respiration rate of oat plants at milk stage

\begin{tabular}{lllll}
\hline & & \multicolumn{2}{c}{$\begin{array}{c}\text { Dark respiration rate - } \\
\text { in } \mathrm{mg} \cdot \mathrm{h}^{-1} \cdot \mathrm{g}^{-1} \mathrm{DWt}\end{array}$} \\
\cline { 3 - 5 } Year & \multirow{2}{*}{ Kind of a shoot } & \multicolumn{3}{c}{$\mathrm{Cu}-\mathrm{mg} / \mathrm{pot}$} \\
\hline \multirow{2}{*}{1977} & main & 0 & 5 & 125 \\
\hline \multirow{2}{*}{1979} & shoot & 2.5 & 1.0 & 1.1 \\
& \multirow{2}{*}{ tillers } & 2.1 & 1.9 & 0.6 \\
& & 2.7 & 2.3 & 0.9 \\
\hline
\end{tabular}

The respiration intensity of oats varied during the vegetation but differences in respect of copper supply and part of plant were slight. The highest value of plant respiration rate in the treatment $\mathrm{Cu}-0$ and $\mathrm{Cu}-5$ was found at the stage of heading $\langle$ Fig. 1$\rangle$. At the subsequent stages the intensity decreased, reaching the lowest value towards the end of the milk ripeness. For the $\mathrm{Cu}-125$ plants, the highest value of respiration intensity was noted in the period preceding heading. Upon these conditions the decrease in intensity was more pronounced, and the lowest value was found at full grain ripeness.

An addition of copper to $\mathrm{Cu}-0$ plants during tillering or shooting caused a reduction of the respiration intensity of plants 〈especially of the main shoots〉, as compared with the high respiration level of plants growing under the conditions of $\mathrm{Cu}$ deficiency $\langle$ Fig. 2〉. At later stages $\langle$ heading and flowering $\rangle$ copper supply did not depress the respiration intensity.

Statistical evaluation confirmed the significance of the differences in respiration intensity, both in the case of main and of lateral shoots. These differences were especially pronounced in plants treated with the optimal copper dose before emergence, during tillering and shooting as compared with plants growing the whole time under conditions of copper deficiency and also those which received $\mathrm{Cu}$ at heading or flowering.

\section{DISCUSSION}

The present investigations demonstrated that the changes in respiration intensity of oats dependent on the plant developmental stage and degree of copper supply exhibited a distinct character. Over all the years of the study, from the stage of heading or grain filling a higher intensity of respiration of the main shoots was observed in the treatment $\mathrm{Cu}-0$, as compared with that of plants 
receiving an optimal supply of $\mathrm{Cu}$. In plants growing under conditions of copper deficiency <mostly without heading it was probably caused by the excessive utilization of assimilates in the process of enhanced respiration. Whereas in plants optimally supplied with $\mathrm{Cu}$, in which the respiration rate was markedly lower, the assimilates were mainly transported to the grain.

The phenomenon of unproductive respiration of plants caused by the influence of unfavourable factors has been observed, among others, by $\mathrm{K} \mathrm{u} \mathrm{s} \mathrm{h} \mathrm{n} \mathrm{i} \mathrm{r} \mathrm{e} \mathrm{n} \mathrm{k} \mathrm{o} \mathrm{\langle 1961〉} \mathrm{in} \mathrm{the} \mathrm{case} \mathrm{of} \mathrm{root} \mathrm{chilling} \mathrm{in} \mathrm{thermophilous} \mathrm{plants}$ and $S t$ o y $\langle 1965\rangle$ after ear cutting. The headed shoots showed a higher respiration rate as compared with the control, not only because they were physiologically younger, but also on account of the higher retention of soluble assimilates, serving as respiratory substrate. This has been confirmed by the results of Ś l u s a r c z y k $\langle 1980\rangle$ concerning the carbohydrate content in plant material used in the experiments described in the present paper. The low hexose content in intensively respirating plants, which show symptoms of copper deficiency was an evidence of the high consumption of carbohydrates - main respiratory substrates.

The different intensity of plant respiration in the $\mathrm{Cu}-5$ treatment $<1977$ and $1979>$, as compared with that in plants with a high copper deficiency and those optimally supplied, is in good agreement with the above reported dependence. In the first year of measurements, the low degree of respiration of $\mathrm{Cu}-5$ plants observed from stage of milk ripeness may be explained by a greater transport of assimilates to the grain 〈in 1977 the plants had panicle〉, instead of their utilization in the process of unproductive respiration. In 1979, however, the oats did not from the panicle and the respiration rate was close to the high respiratory value in plants showing copper deficiency symptoms, which also did not from panicles. It has been known that in cases of severe copper deficiency heads and panicles did not from. The above discussed relation corresponded to the different copper contents in the plants in these two years $\langle\mathbf{C u}-5$ in 1977: leaves $-5.7 \mathrm{ppm} \mathrm{Cu}$, culm - $3.8 \mathrm{ppm} \mathrm{Cu}$, and in 1979: leaves - $2.4 \mathrm{ppm} \mathrm{Cu}$ and culm $-1.8 \mathrm{ppm} \mathrm{Cu}$.

The decreased respiration rate was found in copper-deficient plants when this nutrient was supplied at the tillering and shooting stages as compared with the high respiration intensity of plants growing throughout the vegetation period under conditions of $\mathrm{Cu}$ deficiency. That probably have been due to the fact that copper, involved in carbohydrate metabolism 〈Grigoryuk et al., 1975, van Schreven, 1936 - quoted by $\mathrm{G} \mathrm{r}$ a h a $\mathrm{m}, 1980\rangle$, improves the utilization of the assimilates produced 〈at earlier developmental stages〉 in the grain filling. The high intensity of respiration of plants supplied with copper later than at the shooting stage <as compared with plants supplied with $\mathrm{Cu}$ from the beginning of vegetation $>$ is probably one of the causes of the low grain yield. $\mathrm{G} \mathrm{r} \mathrm{a} \mathrm{h} \mathrm{a} \mathrm{m}$ $\langle 1980\rangle$ has observed a rapid decrease in concentration of carbohydrates after fertilization in the treatment with a high $\mathrm{Cu}$ supply. He has attributed it to the 
translocation of these substances to the grain. Under the conditions of low copper level where, owing to sterility, no grain was produced, and thus there was no acceptor of soluble assimilates, they were accumulated in various tissues. According to this author, plants poor in copper contained less soluble assimilates at the beginning of the season and more at the late stages of development as compared 'with those receiving a sufficient $\mathrm{Cu}$ supply. The accumulation of soluble carbohydrates caused not only profuse tillering of the plants, characteristic of the late developmental stages of cereal plants deficient in copper, but also an enhanced respiration intensity.

The rapid increase in reducing sugar content observed by Brown and Harmer 〈quoted by $\mathrm{B} \mathrm{r}$ ow $\mathrm{n}$ et al., 1958 > in wheat plants well supplied in $\mathrm{Cu}$, in contrast to deficient plants, seemed to indicate considerable differences in metabolism under the influence of copper. These changes have been also described by S 1 u s a r c z y k $\langle 1980\rangle$. She has suggested that the break-down of glucose in the process of ration may occur, to a higher degree, on the pentosephosphate pathway, under the copper deficiency than under optimal conditions for the plant growth. This would explain, to some extent, the cause of enhanced respiration of copper-deficient plants, owing to the small amount of ATP arising in this process.

Suggestions presented there have been confirmed in detailed determinations of the content and composition of the individual sugar fractions in plants receiving copper at various stages of development, and will be the subject of a separate publication.

\section{CONCLUSIONS}

1. Copper supply had an important effect on the dark respiration rate of oat plants; this influence also depended on the plant developmental stage. Up to the heading or grain filling, the respiration intensity of the main shoot of plants deficient in copper $\langle\mathrm{Cu}-0\rangle$ was lower as compared with plants growing under optimal conditions of $\mathrm{Cu}$ supply $\langle\mathrm{Cu}-125\rangle$. At the further stages a reversed relation was observed.

The respiration rate of tillers of copper-deficient plants was, notwithstanding the developmental stage, higher than that in tillers of plants sufficiently supplied with copper.

2. In all copper treatments the intensity of respiration of tillers was higher than that of the main shoot.

3. Copper, supplied at the stage of tillering or of shooting to deficient plants, reduced the respiration rate as compared with the high respiratory level of plants growing throughout the vegetation period under conditions of $\mathrm{Cu}$ deficiency.

4. The enhanced respiration intensity of copper-deficient plants was the result of unproductive utilization of assimilates owing to the lack of the main acceptor of photosynthesis products which under normal conditions would be the developing grain. 


\section{REFERENCES}

B a sz yński T., R uszk ow sk a M., K ról M., Tukendorf A., Woliń$s \mathrm{k}$ a D., 1978. The effect of copper deficiency on the photosynthetic apparatus of higher plants. Z. Pflanzenphysiol 89: 207-216.

B r o w n J. C., T if $\mathrm{f}$ i L. O., Hol m e s R. S., 1958. Carbohydrate and organic acid metabolism with $\mathrm{C}^{14}$ distribution affected by copper in Thather wheat. Plant Physiol. 33: 38-42.

G r a h a m R. D., 1975. Male sterility in wheat plants deficient in copper. Nature 254: 514-515.

$\mathrm{G} \mathrm{r}$ a h a m R. D., 1976. Physiological aspects of time of application of copper to wheat plants. J. Exp. Botany 27: 717-724.

G r a h a m R. D., 1980. The distribution of copper and soluble carbohydrates in wheat plants grown at high and low levels of copper supply. Z. Pflanzenernähr. Bodenkd. 143: 161-169.

Ły s z c z S., Ruszkowska M., Wojcieska U., Zinkiewicz E., 1976. The activity of ascorbic acid and catechol oxidase, the rate of photosynthesis and respiration as related to plant organs, stage of development and copper supply. Acta Agrobot. 29: 99-105.

K u s h n i r e n k o S. W., 1961. Neproduktivnoe dykhanie listev i ustoichivost teplolubnykh rastenii k okhlazhdeniyu kornevykh sistem. Fiziol. Rast. 8: 345-352.

$\mathrm{N}$ a m b i a r. E. K. S., 1976. Genetic differences in the copper nutrition of cereals: I. Differential responses of genotypes to copper. Aust. J. Agric. Res. 27: 453-463.

$\mathrm{N}$ a m b i a r E. K. S., 1976. Genetic differences in the copper nutrition of cereals: II. Genotypic differences in response to copper in relation to copper nitrogen and other mineral contents of plants. Aust. J. Agric. Res. 27: 465-477.

Os t r ovsk a y a L. K., 1961. Fiziologicheskaya rol medi i osnovy primeneniya mednykh udobrenii. Izd. AN Ukrainskoi SSR, Kiev: 1-284.

R a h i m i A., B u s s le r W., 1973. Die Wirkung von Kupfermangel auf Gewebestruktur höherer Pflanzen. Z. Pflanzefernähr. Bodenkd. 135: 185-195.

R u s z k o w sk a M., L y s z c z S., 1971. Próba określenia fizjologicznych wskaźników zaopatrzenia roślin w miedź. Pam. Pul. 47: 33-53.

R u s z k ow sk a M., L y s z c z S., 1975. Wplyw dawek NPK i Cu na plony oraz pobieranie miedzi i azotu przez rośliny w warunkach doświadczeń wazonowych. Pam. Puł. 62: 229-250.

R u s z k o w s k a M., Ł y s z c z S., S y k u t S., 1976. Aktywność oksydaz miedzioproteidowych jako wskaźnik zaopatrzenia roślin w miedź. Zesz. Probl. Post. Nauk Rol. 179: 25-30.

S t o y V., 1965. Photosynthesis, respiration, and carbohydrate accumulation in spring wheat in relation to yield. Physiol. Plant. suppl. 4: 1-125.

Śl u s a r c z y k M., 1980. Zmiany w zawartości i składzie frakcji węglowodanowych owsa w warunkach niedoboru miedzi. Doniesienie plakatowe. Streszczenia - XLV Zjazd P. T. Bioch. Lublin: 87-88.

Szuka lski H., Nate r K., W lod a r czyk K., Sik or a H., S a m s on S.,1980. Badania nad wpływem miedzi na plonowanie intensywnych odmian zbóż oraz efekty wdrożeń $z$ zastosowaniem superfosfatu miedziowego. Nowe Rol. 22: 3-7.

Wer y s z o E., R u s z k o w s k a M., T o m a s ze w s k i A., 1983. Zmiany w kwiatach i kwiatostanach owsa (Avena sativa L.> w warunkach niedoboru miedzi. Acta Agrobot. 36: 49-57

W o j c i e s k a U., 1982. Fizjologiczna rola miedzi w plonowaniu owsa. Cz. I. Wpływ dawki miedzi na wielkość i strukturę plonu. Pam. Pul. 77: 109-130.

W o j c i e s k a U., 1982. Fizjologiczna rola miedzi w plonowaniu owsa. Cz. Il. Wpływ terminu stosowania miedzi na wzrost $\mathrm{i}$ rozwój roślin. Pam. Pul. 77: 131-142.

W o j c i e s k a U., 1983. Fizjologiczna rola miedzi w plonowaniu owsa. Cz. III. Wpływ miedzi na fotosyntezę i aktywność reduktazy azotanowej. Pam. Puł. 79: 63-83.

W o j c i e s k a U., 1983. Fizjologiczna rola miedzi w plonowaniu owsa. Cz. IV. Wpływ niektórych substancji wzrostowych na wzrost i rozwój owsa w warunkach niedoboru miedzi. Pam. Puł. 79: 85-101. 
Z i n k i e w i c z E., 1978. Oddychanie roślin na tle różnego poziomu miedzi. Doniesienie plakatowe. Streszczenia - XVI Zjazd P. T. Bioch. Lódź: 91-92.

Zink ie wi c z E., R uszk ow sk a M., Wo j cieska U., Wolska E., 1980. The productivity of oat plants in dependence on copper nutrition. Abstracts of lectures and poster demonstrations. FESPP Congres II, Santiago de Compostela: 740-741.

Z i n k i e w i c z E., Ślu s a r c z y k M., 1981. Wpływ miedzi na intensywność oddychania ciemniowego oraz na zawartość i skład węglowodanów owsa. Doniesienie plakatowe. Streszczenia - XVIII Zjazd P.T.Bioch. Wrocław: 286-287.

\title{
Intensywność oddychania ciemniowego owsa przy różnym zaopatrzeniu w miedź
}

\author{
Streszczenie
}

Celem pracy było wyjaśnienie wpływu miedzi na intensywność oddychania ciemniowego owsa odm. 'Udycz Żółty' w różnych fazach rozwoju roślin przy kilku poziomach zaopatrzenia w miedź i zróżnicowanym terminie jej stosowania.

Intensywność oddychania ciemniowego roślin owsa z niedoborem miedzi do fazy kłoszenia była niższa w porównaniu do roślin dobrze zaopatrzonych $w$ ten składnik. Po kłoszeniu stwierdzono odwrotną zależność. Wysoka intensywność oddychania ciemniowego roślin owsa deficytowych $\mathrm{w}$ miedź po kłoszeniu była prawdopodobnie wynikiem nieproduktywnego zużywania asymilatów w przypadku braku głównego akceptora produktów fotosyntezy, jakim w normalnych warunkach są rozwijające się ziarniaki.

Dostarczenie miedzi $\mathrm{w}$ fazie krzewienia $\mathrm{i}$ strzelania $\mathrm{w}$ źdźbło roślinom pozbawionym tego składnika od początku wegetacji powodowało obniżenie natężenia oddychania w porównaniu do wysokiej intensywności oddychania roślin rosnących przez cały czas wegetacji w warunkach niedoboru tego pierwiastka.

We wszystkich kombinacjach zróżnicowanego nawożenia miedzią intensywność oddychania pędów bocznych była wyższa niż pędów głównych. 